\title{
Oorreding in Romeine 11
}

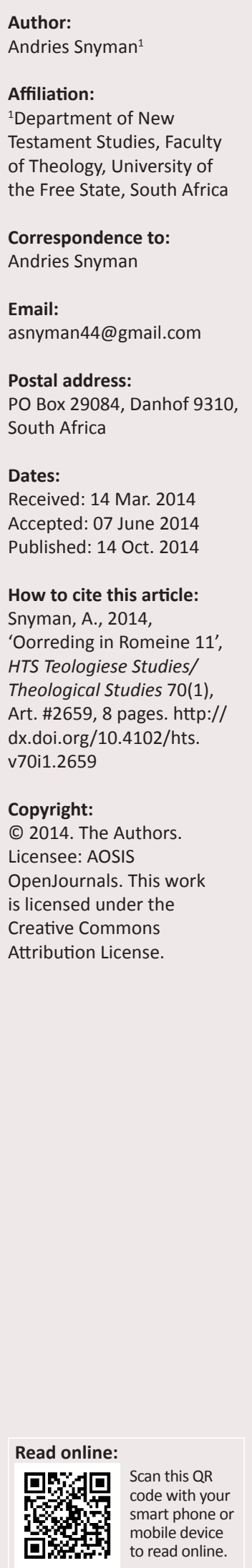

Persuasion in Romans 11. A new trend in the rhetorical analysis of Paul's epistles is to reconstruct his rhetorical strategy from the text itself, rather than applying ancient or modern rhetorical models to his letters. A proposal for such a text-centred approach is briefly summarised in this article, followed by a discussion on the rhetorical situation that Paul wishes to address in his letter to the Romans. It is argued that chapter 11 forms an integral part of his rhetorical strategy as reconstructed from the text itself, and that it is aimed at persuading his audience in Rome to support his view on God's plan of salvation, as well as his forthcoming mission to Spain. The conclusion is that a text-centred approach (with its focus on the functional aspects of the text) provides a better alternative to existing approaches (which focus on the formal aspects of the text).

\section{Inleiding}

Daar is hoofsaaklik twee benaderings tot die retoriese analise van Paulus se briewe. Die eerste is om 'n model van buite te gebruik om die retoriese struktuur van ' $n$ brief te beskryf. Feitlik al sy briewe is al op dié wyse geanaliseer, en wel deur die Grieks-Romeinse sisteem, met die bekende exordium, propositio, narratio, probatio en peroratio, te gebruik. In die tweede benadering word die studie van retoriek beperk tot ' $n$ paar retoriese tegnieke en stylfigure. Sporadiese opmerkings hieroor word in die meeste kommentare gevind, maar selde word probeer om hulle binne 'n bepaalde raamwerk te ondersoek of hulle funksies binne konteks te bepaal.

In onderskeiding van bogenoemde twee benaderings, word retoriese analise in hierdie artikel verstaan as 'n beskrywing van al die middele in die teks (wyse van redenering, tipes argumente en retoriese tegnieke) wat die outeur ter stawing gebruik om sy lesers tot sy standpunt te oorreed. 'n Model van buite word nie op die teks afgedwing nie, maar alles wat bydra tot die proses van oorreding word geïdentifiseer en hulle funksie binne konteks beskrywe. 'n Voorstel vir so 'n teksgesentreerde metode van retoriese analise is die gepubliseerde proefskrif van Francois Tolmie: Persuading the Galatians (2005). Hy beskryf sy voorstel as 'n 'minimal theoretical framework to guide the analysis' (2005:28) en beklemtoon dat dit nie verstaan moet word as 'n rigiede metode wat stip op die teks toegepas moet word nie. Sy voorstel het heelwat byval gevind en kan soos volg opgesom word:

- 'n Beskrywing van die retoriese situasie van die brief, dit wil sê wát Paulus in die brief as geheel wil bereik.

- 'n Ontleding van hóé hy sy lesers probeer oorreed, gebaseer op sy 'minimal theoretical framework', wat uit die volgende elemente bestaan: die identifisering van die dominante retoriese strategie in elke gedeelte of fase deur die primêre retoriese doel daarvan te beskryf en aan te dui hoe hy probeer om dit te bereik. In die proses val die klem op die wyse waarop hy redeneer en die tipes argumente wat hy gebruik om sy gehoor te oorreed. Ten slotte word die sogenaamde retoriese tegnieke, wat dien om die trefkrag van sy kommunikasie te verhoog, geïdentifiseer en hulle funksies beskryf.

Die doel van die artikel is om Tolmie se voorstel vir retoriese analise op Romeine 11 toe te pas en sy waarde te bepaal deur die proses van oorreding aan die hand daarvan te beskryf.

\section{Retoriese situasie}

As vertrekpunt van hierdie studie word aanvaar dat Paulus die Romeine tot sy standpunt oor 'n bepaalde saak of sake wou oorreed. Sonder om te herhaal wat in enige goeie kommentaar gevind kan word, sluit ek graag aan by twee sake wat Jewett $(2007: 41-42,80)$ in sy standaardwerk uitgelig het. Die eerste is die bestaan van verskillende huiskerke in Rome, wat onderling verskil het oor leerstellige aangeleenthede. Met die brief probeer Paulus die konflikte tussen veral die Joodse en heidense christene bylê deur klem te lê op die kernboodskap van die evangelie wat hy geroep 
is om aan die hele wêreld te verkondig: regverdigmaking deur die geloof in Jesus Christus alleen (1:17). Hierop fokus Paulus in die eerste elf hoofstukke van die brief en toon aan dat alle mense (Jode, sowel as nie-Jode) vrygespreek is as hulle in Christus glo, en dat hulle as vrygespreekte mense moet lewe. Die posisie van die volk Israel in die hele proses van verlossing is vir hom van buitengewone belang en daarom gebruik hy soveel treffende oorredingsmiddele in hoofstukke 9-11, wat juis oor die onderwerp handel. Met die brief wil hy sy gehoor waarsku teen 'dié wat verdeeldheid veroorsaak en die mense afvallig maak van die leer wat julle ontvang het' (16:17).

'n Tweede saak blyk uit hoofstuk 15, wat handel oor Paulus se toekomsplanne in die uitvoering van sy taak as apostel aan die heidene. Hy is op die punt om 'n nuwe arbeidsveld te betree en die evangelie in die Weste (Spanje) te gaan verkondig (15:23-24). Om dit te doen moes hy in Rome aandoen vanweë die belangrike rol wat die gemeentes daar in die kerk van die Weste vervul het; vandaar sy voorneme om "n tydjie by julle deur te bring en dan met julle hulp verder na Spanje toe te reis' (15:24). Deur sy brief wil hy dus die band met die gemeentes in Rome versterk en so hulle ondersteuning kry vir sy voorgenome besoek aan Spanje, wat sy wêreldwye sendingtaak sou voltooi.

\section{Analise van Romeine}

Geleerdes wat verkies om die Grieks-Romeinse retoriese sisteem te gebruik om Paulus se briewe te analiseer, verskil oor die indeling van die brief aan die hand van dié sisteem. Volgens Jewett (2007:viii-ix) is 1:1-12 die exordium, 1:13-15 die narratio, 1:16-17 die propositio, 1:18-15:13 die probatio en 15:14-16:24 die peroratio daarvan. Talbert (2002:14) volg dieselfde indeling, terwyl Reid (1995:117-139) die brief verdeel in die exordium (1:8-15), transitus (1:16-17), narratio (1:18-3:20), propositio (3:21-31), probatio (4:1-11:36), paraenesis $(12: 1-15: 13)$ en die peroratio (15:14-33). Hoofstuk 16 is vir hom nie deel van die retoriese struktuur nie. Volgens Witherington (2004:21-22) word die brief as geheel ingedeel in die briefopening en groete (1:1-7); exordium (1:8-10); narratio (1:11-15); propositio (1:16-17); probatio (1:18-8:39, wat bestaan uit agt argumente); refutatio (9:1-15:13, met vier argumente) en peroratio (15:14-21), asook mededelings oor sy reisplanne en groetewense (15:22-16:27). Hierdie groot verskeidenheid indelings, waarin dieselfde retoriese sisteem gebruik word, plaas die teoretiese regverdiging vir die gebruik daarvan onder ernstige verdenking. Om dié rede verkies ek om (saam met Tolmie en ander) ' $n$ teksgesentreerde benadering te volg, waar die teks self as vertrekpunt van analise dien.

Dit is interessant dat die meeste persone wat die klassieke sisteem gebruik, hoofstukke 9-11 as 'n eenheid beskou, en wel as deel van die probatio van die brief. Dit word bevestig deur geleerdes wat ' $n$ teksgesentreerde benadering volg. Volgens Louw (1979:97) vorm die drie hoofstukke 'n eenheid:

$[D]$ ealing with Israel in relation to faith as the basis of being put right with God. Though this unit constitutes a section on its own, it links with the previous large section (1:18-8:39) to compose the main part of the letter. In fact, it will be shown by our analysis that 9:1-11:36 actually involves an application to the situation of Israel of the thesis expounded in 1:18-8:39. (p. 97)

Hoofstuk 11 is afgebaken op grond van retoriese oorwegings. Soos genoem, vorm dit deel van die groter fase wat begin in hoofstuk 9 en handel oor die posisie van Israel in die lig van die voorafgaande agt hoofstukke. Die hoofstuk val in vier dele uiteen, wat soos volg afgebaken kan word: 11:1-10 word onderskei van die voorafgaande gedeelte (10:14-21) deur die retoriese vraag: 'Het God dan nie tog sy volk verstoot nie?' (11:1). Die vraag word deur Paulus self beantwoord en strek tot by die volgende retoriese vraag in 11:11: 'Het Israel se struikeling hulle finale val beteken?' Paulus se antwoord in 11:11b-24 word gemerk deur die groot getal voorwaardelike ('as'-) sinne in verse 11:12, 15, 17, 21, 23 en 24, wat dit tot 'n eenheid saambind en oorheers word deur die metafoor van die olyfboom. By 11:25 begin die derde onderdeel van die hoofstuk, wat onderskei word van die vorige een deur die direkte aanspreekvorm 'broers' (à $\delta \varepsilon \lambda \varphi o i ́)$ in vers 25 , die verandering van die tweede persoon enkelvoud in 11:17-24 na die tweede persoon meervoud in 11:25-32 en die bespreking van die 'geheim' ( oorheers. Die hoofstuk word afgesluit met 11:33-36, wat asindeties bind aan die vorige gedeelte en 'n loflied is wat die grootheid van God besing. Die vier dele waarin die hoofstuk ingedeel kan word, is dus 1-10, 11-24, 25-32 en 33-36.

Die dominante retoriese strategie in hoofstuk 11 kan geformuleer word as: Die funksie van Israel in God se verlossingsplan. Die strategie val in die volgende vier dele uiteen:

- Daar is 'n oorblyfsel van Israel, uit genade deur God self verkies (11:1-10).

- Die verlossing van die heidennasies deur Israel se struikeling (11:11-24).

- Die geheim van God se verlossingsplan vir Jode en heidene (11:25-32).

- Alle eer aan God (11:33-36).

Aangesien dié studie primêr 'n retoriese eerder as 'n eksegetiese studie is, val die klem op oorreding. Ten einde Paulus se verskillende oorredingsmiddele reg te verstaan, moet dit wát hy sê egter ook aandag kry. Daar word dus deurlopend aandag gegee aan die hooftrekke van sy diskoers.

\section{Romeine 11:1-10: Daar is 'n oorblyfsel van Israel, uit genade deur God self verkies}

In 11:1 wys Paulus op 'n moontlike afleiding wat gemaak kan word uit die feit dat die heidene die evangelie aanvaar en die Jode dit verwerp het - soos hy in hoofstuk 10 geargumenteer het. Hy doen dit by wyse van 'n retoriese vraag, wat 'n

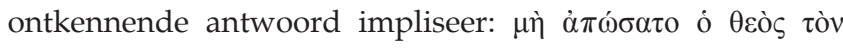

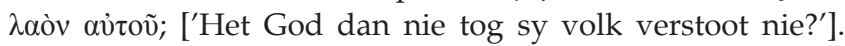

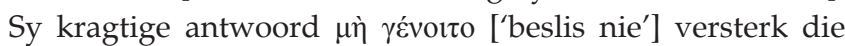
ontkenning, terwyl sy volledige antwoord in 11:2 lees: 'God het sy volk, wat Hy lank tevore verkies het, nie verstoot nie.' 
Vir ons belangrik is die twee argumente wat sy antwoord staaf. In die eerste plek verwys hy na homself as 'ook 'n Israeliet, 'n afstammeling van Abraham, uit die stam Benjamin' (11:1). Sy eie posisie is 'n sprekende bewys dat dit ondenkbaar is om te beweer dat God die Joodse volk verwerp het (Esler 2003:293-294; Kim 2000:135-136). Dit is 'n voorbeeld van wat ek sou wou noem ' $n$ argument gebaseer op persoonlike ervaring. Dié soort argument oorreed omdat Paulus self ' $n$ lewende bewys is van die punt wat hy wil maak: As God sy volk verstoot het, dan sou hy, as volbloed Jood, beslis nie tot die gemeente van Christus behoort het nie.

Tweedens gebruik hy ' $n$ argument wat gebaseer is op die gesag van die Skrif. Paulus gebruik dié tipe argument dikwels in sy brief, en wel vanweë die oorredende krag daarvan. Hier in 11:3-4 kom die aanhalings uit 1 Konings 19:10 en 19 en word hulle ingelei deur die formule ì oủк ơ̌ $\delta \alpha \tau \varepsilon$ ['of weet julle nie?'], wat 'n positiewe antwoord impliseer. In sy uiteensetting stel Paulus die twee aanhalings teenoor mekaar deur die antitetiese $\dot{\alpha} \lambda \lambda \dot{\alpha}$ aan die begin van 11:4. In die eerste aanhaling (1 Kon 19:10) kla Elia by God oor Israel: 'Here, hulle het $\mathrm{u}$ profete doodgemaak en $\mathrm{u}$ altare afgebreek, en net ek het oorgebly en hulle wil my ook om die lewe bring'. Maar ( $\dot{\alpha} \lambda \lambda \dot{\alpha})$ wat het God hom geantwoord? 'Ek het vir My sewe duisend manne laat oorbly wat nie vir Baäl aanbid het nie' (1 Kon 19:18). Sulke Skrifsitate is retories belangrik omdat hulle deur die gehoor as gesaghebbend aanvaar word. Hulle versterk die band tussen Paulus en sy gehoor, bind albei partye aan die God van Israel en word deur Paulus in goed gestruktureerde beredenerings ingebed - dikwels nadat hy hulle ietwat aangepas het om die verband tussen die sitaat en sy argumentasie duideliker te maak (Stanley 1998:712-716).

Naas verskillende tipes argumente, maak Paulus in die gedeelte veral gebruik van antiteses as oorredingsmiddel. Die eerste antitese is tussen Elia se klag en God se antwoord in 11:3-4. Elia se klag is negatief; God se antwoord positief. So 'n antitetiese struktuur is meer oorredend as 'n bloot positiewe of negatiewe stelling, en die fokus val gewoonlik op die tweede deel van die teenstelling (Tolmie 2005:33-34). Hier dui dit op die feit dat God vir Hom sewe duisend manne in Israel laat oorbly het - presies die punt wat Paulus in 11:1-10 wil maak: God het Israel nie heeltemal verwerp nie; daar is 'n oorblyfsel, wat Hy in sy genade uitverkies het (11:5). In die oorspronklike Grieks is die woord 'genade' in die genitief en verbind aan 'verkiesing', wat in effek neerkom op vrye toegang tot God en bepaalde voordele, wat onverdienstelike mense deur Christus se soenverdienste ontvang (Harrison 2003:224-225). Met nog 'n antitese sluit Paulus sy argument af: 'En as dit uit genade is, dan is dit nie uit verdienste nie, anders ( $\dot{\varepsilon} \pi \varepsilon i ́)$ sou die genade nie meer genade wees nie' (11:6).

Verse 7-9 herhaal die eerste ses verse en kom tot 'n gevolgtrekking, soos blyk uit die inleidende vraag ('Waarop kom dit dan neer?') in vers 7: As God nie sy volk verstoot het nie, maar slegs 'n oorblyfsel daarvan bewaar het, wat het dan gebeur? In verse 7-10 beantwoord Paulus self die vraag deur te herhaal dat Israel gefaal het om die soort geregtigheid te kry wat hulle gesoek het, en wel omdat hulle gedink het dat hulle dit op grond van verdienste kon verkry. Die volledige antwoord bevat weer twee antiteses: Wat Israel soek, het hy nie verkry nie, (maar) die uitverkorenes het dit verkry. Die ander (daarenteen), is verhard (11:7). Soos reeds genoem, is sulke antiteses meer oorredend as 'n enkele positiewe of negatiewe stelling, terwyl die fokus in die laaste antitese nogeens val op die tweede deel, die 'ander' (oi $\delta \dot{\varepsilon} \lambda o \imath \pi o i ́)$ wat verhard is. Die verharding word beklemtoon deur Skrifsitate uit Deuternomium 29:3, Jesaja 29:10 en Psalm 68:22-23, wat dieselfde funksie vervul as in 11:3-4 hierbo.

Die woord wat vertaal word met 'is verhard' in 11:7, is $\dot{\varepsilon} \pi \omega \rho \omega \theta \theta \eta \sigma \alpha v$, 'n aoristus indikatief passief. Die aktief beteken: '... to cause to be completely unwilling to learn, to cause the mind to be closed' (Louw \& Nida 1988:333). Lenski (1961:686) wys daarop dat dit 'n sogenaamde goddelike passiewe vorm is, waar die persoon wat die handeling verrig, nie vermeld word nie. Dat God self die handeling verrig, blyk uit die Skrifsitaat wat volg in 11:8: 'God het aan hulle 'n gees gegee wat hulle bedwelm het: oё wat nie sien nie en ore wat nie hoor nie, tot vandag toe nog.' So 'n argument gebaseer op God se betrokkenheid is 'n sterk oorredingsmiddel, omdat dit God, as hoogste gesag vir skrywer en leser, betrek by die handeling en dit dus die einde van alle teenspraak beteken. In sy bespreking van die olyfboom in 11:16-24 gebruik Paulus weer dieselfde soort argument op 'n effektiewe wyse.

Volgens Wagner (2002:265) is die bedwelming van die oorblyfsel 'n tussentydse fase in God se plan om Israel te verlos. Uiteindelik sal God se genade wel die oorhand oor sy volk kry.

\section{Romeine 11:11-24: Die verlossing van die heidennasies deur Israel se struikeling}

Soos in 11:1 begin Paulus ook hier sy bespreking met 'n retoriese vraag: 'Het Israel se struikeling hulle finale val beteken?' (11:11). Hy beantwoord die vraag weer met 'n sterk

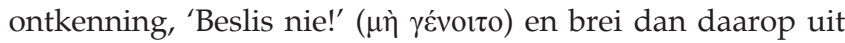
in $11: 11 c-24$. Sy antwoord val in vier dele uiteen: 11:11 stel die basiese tese; 11:12-15 is 'n logiese uitbreiding daarop; in 11:16-21 gebruik hy die metafoor van 'n olyfboom om dit verder te verduidelik; en in 11:22-24 sluit hy sy uiteensetting af met 'n effektiewe konklusie (Jewett 2007:668).

Die tese van sy hele argument, wat dien om die sterk ontkenning te staaf, word ingelei deur $\alpha \lambda \lambda \lambda \alpha$ om so die res van die gedeelte te stel teenoor die vraag of Israel se struikeling hulle finale val beteken het. Die tese is: Nee, want deur Israel se struikeling $(\pi \alpha \rho \alpha ́ \pi \tau \omega \mu \alpha)$ het die redding na die heidennasies toe gekom met die doel om die Jode jaloers te maak. Volgens 11:7-10 moet $\pi \alpha \rho \alpha ́ \pi \tau \omega \mu \alpha$ verstaan word as 'n verwerping van die evangelie. Deur dié verwerping het die redding na die heidennasies gekom. Die geleentheid wat só aan die heidennasies gebied is en waardeur die Jode jaloers gemaak moet word, berus op die apokaliptiese scenario dat die hele Israel aan die einde van die tyd gered sal word 
(11:26). Dié redding sal slegs plaasvind as die volle getal uit die heidennasies in die koninkryk ingegaan het. Dit kom daarop neer dat die Joodse verwerping van die evangelie tyd gee vir die sending na al die heidene. Hierdie redenasie lê ten grondslag van die sending na Spanje, waarvoor Paulus die Romeine se samewerking wil hê (15:23-24). Want: as die evangelie oor die hele wêreld verkondig is, kan die bekering van die Jode plaasvind en die beloofde parousia aanbreek (Käsemann 1980:304).

In die tweede onderafdeling van sy betoog (11:12-15), maak Paulus van verskeie erkende oorredingsmiddele gebruik. Die eerste is die chiastiese struktuur, waarop Louw (1979:111) gewys het: Die Jode se reaksie help die heidene A (v. 12); Paulus as apostel vir die heidennasies - B (v. 13); Paulus as apostel vir die Jode - B (v. 14); die Jode se reaksie help die heidene - A (v. 15). Deur dié struktuur word Paulus se gedagtes op 'n netjiese wyse georden en die aandag van die gehoor op die inhoud daarvan gevestig. Die twee A-gedeeltes (11:12 en 15) bevat elkeen 'n argument a minore ad maius (van die mindere na die meerdere), wat 'n erkende Joodse eksegetiese tegniek was (Tolmie 2005:124). Die logika van die argument is die volgende: die oorblyfsel van die Jode wat die evangelie geglo het, het die heidennasies gehelp om tot geloof te kom; hoeveel te meer is dit nie waar as al die Jode tot geloof in die evangelie sou kom nie! Op dié wyse word prominensie verleen aan Israel se rol in God se verlossingsplan.

Die B-gedeeltes (11:13 en 14) bevat elkeen 'n argument gebaseer op voorbeeld. In die twee verse praat Paulus direk met die gelowiges uit die heidennasies (11:13) en probeer hy hulle oorreed om sy voorbeeld te volg deur uit te reik na ander nasies. Gevolglik maak hy dit duidelik dat so 'n uitreikaksie soos die een wat hy na Spanje beplan, eie is aan sending na die heidene en gebruik hy homself as voorbeeld om na te volg. In die oorspronklike Grieks word die argument versterk deur

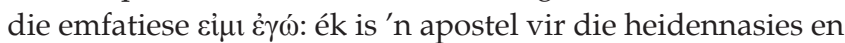
trots daarop (11:13)! Saam met die goddelike sanksie van sy apostelskap (soos blyk uit sy roeping tot apostel in 1:1 en 1:5), moes dié argument 'n sterk oorredingskrag gehad het.

In aansluiting by God se rol in sy roeping as apostel na die heidene, formuleer Paulus sy taak op 'n versigtige wyse in 11:14. Sy strewe is dat sy werk op die een of ander manier ( $\varepsilon$ 'i $\pi \omega \varsigma$ ) 'sy eie mense jaloers kan maak en sommige van hulle tot verlossing kan bring' - soos die 2014-vertaling dit tereg vertaal. Jewett (2007:679) wys daarop dat die werkwoordsvorme $\pi \alpha \rho \alpha \zeta \eta \lambda \omega \sigma \omega$ ['jaloers maak'] en $\sigma \omega \sigma \omega \omega$ ['red'] albei verstaan kan word as futurum indikatief of aoristus subjunktief, wat 'n belangrike verskil aan die vertaling daarvan maak. Hy kies die aoristus subjunktiewe vorm, en wel in die lig van die versigtige formulering cil $\pi \omega \varsigma$, wat die werkwoorde voorafgaan, sowel as die 'sommige' wat gered kan word. Jewett se interpretasie oortuig en gevolglik stem ek saam met sy vertaling van die aoristus subjunktiewe vorm as 'might make jealous' en 'might save'. Deur sy versigtige woordkeuse gebruik Paulus hier weer 'n argument gebaseer op goddelike betrokkenheid. Met dié argument laat Paulus die oorreding van die Jode, wat steeds weerstand bied teen die evangelie, in God se hande. Sy strewe is dat sy werk op een of ander manier sy eie mense jaloers sal maak en sommige van hulle sal red.

In 11:16b begin die derde onderdeel van die fase 11:11-24 - en nie by 11:17, soos Louw (1979:112) dit sien nie. Die rede is omdat $11: 16 \mathrm{~b}$ reeds begin met die metafoor van die olyfboom, wat strek tot by vers 24 . Die kern daarvan is dat die heidene geen rede het om hoogmoedig te wees nie: dit is slegs die goedheid van God wat hulle gered het en Hy is by magte om dieselfde vir Israel te doen. Die metafoor van die olyfboom is die belangrikste oorredingsmiddel wat in 11:11-24 gebruik word (Maartens 1997:1007-1009; Witherington 2004:240). 'n Metafoor is 'n skuif in verwagting met betrekking tot die kommunikasieproses - gewoonlik van 'n letterlike na 'n figuurlike betekenis (Nida et al.1983:186). Op dié wyse word die gehoor voorsien van 'n nuwe, ongewone kyk op 'n saak, wat hulle aandag skerper daarop fokus (Tolmie 2005:99). Paulus se basiese stelling is dat 'as die wortel van die boom aan God gewy is, dan is ook die takke aan Hom gewy' (11:16). Die parallellisme tussen 11:16a en 11:16b beklemtoon dat die beginsel wat vir die een geld, ook vir die ander geld. Hierdie beginsel van uitgebreide wyding of heiligheid wys op Israel se sentrale rol in die totstandkoming van God se volk op aarde: deur Israel het die heilige kerk van God in die wêreld in gekom (Maartens 1997: 1018-1019). In 11:17 word dit verwoord en op die christene uit die heidendom toegepas: 'Party van die takke is uitgekap en jy, 'n wilde olyf, is tussen die ander takke op die mak olyf geënt. So het jy deel gekry aan die lewensap van die mak olyf se wortel.'

Benewens die funksie van die metafoor, is die volgende twee punte ook belangrik vanuit ' $n$ oorredingsperspektief. Die eerste is weer die passiewe vorm, naamlik 'is uitgekap' ( $\dot{\varepsilon} \xi \varepsilon \kappa \lambda \alpha ́ \sigma \theta \eta \sigma \alpha v)$, wat deur Dunn (1988:660) gedefinieer word as 'n passivum divinum. 'n Argument gebaseer op goddelike betrokkenheid is dus effektief omdat gelowiges God se gesag aanvaar en in sy beskikking berus. Dit is vir hulle die einde van alle teenspraak. In die gang van die argument in hoofstuk 11 is dit ook belangrik dat God net 'party van die takke' afgebreek en sy volk as geheel nie verwerp het nie. Tweedens skakel Paulus in 11:17 van die derde persoon meervoud in 11:11-16 oor na die tweede persoon enkelvoud, waardeur hy elke individu direk aanspreek: jy, as 'n wilde olyf, is tussen die ander takke op die mak olyf geënt. Die gespreksgenoot is 'n christen uit die heidendom, wat as verpersoonlikte tak van die wilde olyfboom op die mak olyfboom van Israel ingeënt word (Tobin 2004:363), terwyl die gesprek tussen 'jy' en 'hulle' (dit is die ongelowige Jode) voortgesit word tot by 11:24. Die tweede persoon enkelvoud ( $\sigma 0 ́)$ in vers 17 staan aan die begin van die betrokke sinsdeel in ' $n$ beklemtoonde posisie en verleen 'n lewendige effek aan die argument (Anderson 2000:237-238; Witherington 2004:179).

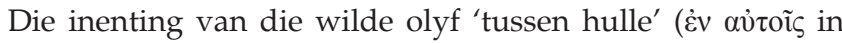
11:17) verwys binne konteks na die takke wat nie afgebreek is 
nie, dit wil sê na die Joodse christene. Die werkwoord 'geënt'

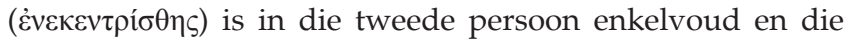
passiewe vorm is weer ' $\mathrm{n}$ passivum divinum, wat goddelike betrokkenheid impliseer.

In 11:18 bou Paulus voort op die metafoor van die olyfboom wanneer hy waarsku: 'Moet jou dan nie bo die ander takke verhef nie! Moet jou ook nie verbeel jy is iets nie: dit is nie jy wat die wortel dra nie, die wortel dra jou.' Die Griekse term

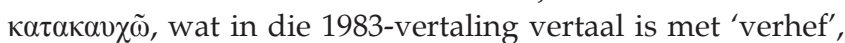
word deur Louw en Nida (1988:431) gedefinieer as 'to boast about something by downgrading something else - to boast against, to degrade'. Hulle vertaling van 11:18 lees: 'You must not boast and in so doing degrade the branches.' Die persone teenoor wie die gespreksgenoot nie moet roem nie, is al die takke, wat verstaan moet word as die Jode wat afgebreek is én die wat reeds in die nuwe geloofsgemeenskap ingelyf is (Dunn 1988:661-662).

As verteenwoordiger van die heidense christene merk die gespreksgenoot in 11:19 op: 'Jy sal wel sê: "Takke is uitgekap sodat ék daar geënt kon word".' Hiermee werp hy die woorde, wat Paulus self in 11:17 gebruik het (naamlik 'takke', 'afgebreek' en 'ingeënt'), terug in sy gesig - 'n retoriese tegniek bekend as prokatalēpsis (Anderson 2000:104). In 11:20-21 reageer Paulus hierop, met vers 20a wat die antwoord gee ('Dis waar') en 20b wat dit kwalifiseer en in die regte perspektief plaas: 'Wat julle as christene uit die heidendom beweer, is korrek, maar dit is nie júlle prestasie nie. Dit is deur geloof dat julle op die olyfboom geënt is en dis deur ongeloof dat die Jode nie geënt is nie.' Laasgenoemde is die implisiete rede waarom die heidene geen rede het om te roem nie.

Die antitese van geloof of ongeloof as reaksie op die evangelie, is vir ons doel belangrik. Die funksie daarvan is om die verskil te beklemtoon tussen die heidense christene en die Jode wat nie geënt is nie, en die gespreksgenoot daaraan te herinner dat heidense christene geen rede het om te roem nie: Hulle roem sou die nuwe verhouding, waarin hulle staan en wat deur en deur gegrond is op geloof, misken. Die antitese word opgevolg deur nog een in 11:20b wat ook 'n vermaning bevat: 'Moenie daaroor hoogmoedig wees nie; hou rekening met God ...' Die rede is: '... want as Hy die natuurlike takke nie ontsien het nie, sal Hy jou dalk ook nie ontsien nie' (11:21). Die antitese in 11:20b word duidelik uitgelig deur die teenstellende $\dot{\alpha} \lambda \lambda \dot{\alpha}$, terwyl die werkwoordstam van $\varphi \circ \beta$ ĩ in al sy definisies in Louw en Nida se woordeboek die komponent van 'vrees', 'eerbied' of 'ontsag' bevat (Louw \& Nida 1988:316, 735 en 540-541). Gevolglik word voorgestel dat die antitetiese $\dot{\alpha} \lambda \lambda \dot{\alpha}$ wat in die 1983-vertaling 'hou rekening met God' lui, vervang word deur 'wees vol ontsag vir God' - in pas met 2014 se Nuwe Testament en Psalms: 'n Direkte vertaling. Soos hierbo aangetoon, is 'n antitese 'n kragtiger oorredingsmiddel as ' $n$ enkele stelling en vra dit gewoonlik aandag vir die tweede deel van die teenstelling. Hier: geloof as die enigste rede waarom die heidene geënt is en die oproep om ontsag vir God te hê. Die rede waarom hulle God moet eerbiedig, is omdat Hy hulle ook kan uitkap (11:21). Die funksie van die antiteses in 11:20 is om te beklemtoon dat die hoogmoedige, heidense gespreksgenoot wat teen die Jode roem, die gevaar loop om sy plek op die olyfboom te verloor - 'n plek wat hy slegs op grond van sy geloof verkry het.

In 11:22-24 sluit Paulus sy bespreking van die metafoor af met 'n oproep:

Let dan op die goedheid en strengheid van God: sy strengheid oor die afvalliges, en sy goedheid oor jou. Maar dan moet jy uit sy goedheid lewe, anders kan jy ook uitgekap word.

Hierdie argument gebaseer op God se betrokkenheid, word gevolg deur 'n laaste een in 11:23: 'En wat hulle betref, as hulle nie in hulle ongeloof volhard nie, sal hulle ook geënt word ...' Die rede wat volg, spel God se betrokkenheid volledig uit: '... want God is in staat/het die mag om hulle terug te ent.' Vers 24 som die hele argument vanaf 11:16 op en sluit dit effektief af met 'n laaste antitese en a minore ad maius argument:

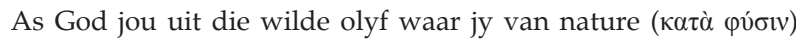

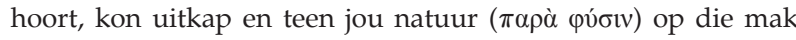
olyf kon ent, hoeveel te meer sal Hy die mak takke op hulle ou boom ent.

Op hierdie wyse kry ál die takke (die wat afgebreek is en die nuwes wat geënt is) deel aan dieselfde olyfboom.

Retoriese tegnieke wat Paulus se kommunikasie in 11:11-24 versterk, sluit in:

- die sinonieme parallellisme in 11:12 ('As hulle val 'n verryking van die wêreld beteken het en hulle klein oorblyfseltjie 'n verryking van die heidennasies'), wat die basiese tese aan die einde van 11:11 herhaal en dit beklemtoon

- die tegniek van parachēsis (dit is die gebruik van woorde wat dieselfde klink naby aan mekaar ter wille van

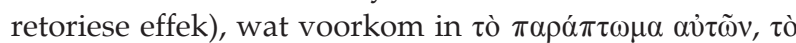

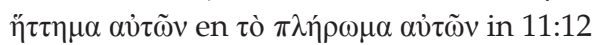

- die plasing van v́rĩv in 'n emfatiese posisie aan die begin van 11:13, wat beklemtoon dat Paulus hom nou primêr tot die gelowiges uit die heidennasies wend

- die sintetiese parallellisme in 11:16, wat die bespreking van die metafoor van die olyfboom inlei en die inhoud daarvan beklemtoon

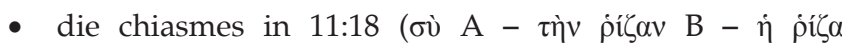

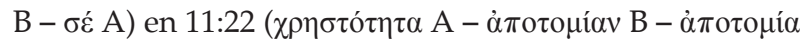
$\mathrm{B}-\chi \rho \eta \sigma \tau$ tón $\mathrm{A}$ ). Die funksie van die stylfiguur is - soos reeds genoem - om deur die netjiese ordening van terme of gedagtes die aandag van die gehoor op die inhoud daarvan te vestig.

\section{Romeine 11:25-32: Die geheim van God se verlossingsplan vir Jode en heidene}

In die nuwe onderdeel van hoofstuk 11 maak Paulus dit duidelik dat hy nie wil hê dat die heidene onkundig moet 
wees oor die geheim en inwerkingstelling van God se toekomstige plan van verlossing vir beide Jode en heidene nie. Hy verduidelik die verlossingsplan aan die hand van drie fases: die verwerping van die evangelie deur die Jode, die aanvaarding daarvan deur die volle getal uit die heidennasies en dan die redding van die hele Israel (Fitzmyer 1993:621; Witherington 2004:272). Soos gewoonlik word sy verduideliking gesteun deur erkende oorredingsmiddele, asook deur verskeie retoriese tegnieke.

Die nuwe onderdeel word aan die vorige argument in 11:23-24 verbind deur die partikel $\gamma \alpha \dot{\alpha} \rho$, wat ongelukkig in die Afrikaanse vertalings van 1983 én 2014 weggeval het. Sulke bindpartikels as deel van die oorspronklike teks is belangrik om die wyse te volg waarop Paulus argumenteer. Laasgenoemde is deel van sy hele oorredingstrategie, soos onder die Inleiding (punt 1 hierbo) aangedui. Afhangend van die konteks, kan róp vertaal word met 'want' / 'dan' / 'immers'. Vers 25 en volgende is juis 'n verdere verduideliking van die stelling in 11:23-24 dat Israel weer op die olyfboom geënt sal word. Dit is die $\mu v \sigma \tau$ prov wat die Romeine moet weet en wat in 11:25b en 26 onthul word: 'Die verharding het oor 'n deel van Israel gekom en duur totdat die volle getal uit die heidennasies in die koninkryk ingegaan het; en op hierdie manier sal die hele Israel gered word.' Paulus ken die verharding van Israel omdat hy en verskeie van sy medebekeerlinge uit die Jodedom daarin gedeel het. Die eerste element in die geheim is dus dat slegs ' $n$ deel van Israel die evangelie verwerp het en dat die dwaasheid uiteindelik oorkom sal word.

Die dwaasheid sal oorkom word wanneer 'die volle getal uit die heidennasies in die koninkryk ingegaan het'. Dit is die tweede element in die geheim. Die volle getal heidene verwys hier na die voorafbepaalde getal uitverkorenes volgens 'n bepaalde apokaliptiese of eskatologiese skema (Jewett 2007:700). Paulus gebruik dieselfde woord hier as in 11:12 vir die volle getal Joodse bekeerlinge, naamlik $\tau$ ò $\pi \lambda \eta ́ \rho \omega \mu \alpha$. Dit stel die Jode en die heidene gelyk: dit gaan oor die inbring van 'n voorafbepaalde getal uitverkorenes. In die lig van die retoriese situasie van die brief sluit hierdie volle getal die bekeerlinge in Spanje in - vandaar die noodsaak dat die Romeine hulle samewerking gee vir die sending na Spanje (15:23-24). Die eskatologiese kerk bestaan immers uit die volle getal uitverkore Jode en heidene.

Die derde element in die geheim is die redding van die hele

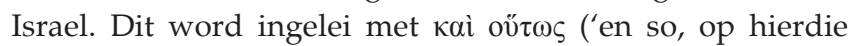
manier'), wat beteken dat die eerste twee elemente van die geheim die manier is waarop God die derde een sal uitvoer (Dunn 1988:681). Geleerdes verskil oor die vraag waarna die woorde $\pi \tilde{\alpha} \varsigma$ 'I $\sigma \rho \alpha \eta ́ \lambda$ ['hele Israel'] verwys. Volgens Dunn (1988:681) verwys dit na Israel as 'n 'corporate identity', wat nie as geheel verlore kan gaan nie - al is daar 'n paar (of selfs baie) individuele uitsonderings. Jewett (2007:702) verskil van hom en reken dat die geheim alle persone in Israel insluit, wat sonder uitsondering gered gaan word. Hy grond sy siening op die feit dat Paulus se sendingvisie wêreldomvattend is en dat God, 'wat dooies lewend maak en dinge wat nie bestaan nie, tot stand bring deur sy woord' (4:17), by magte is om die plan ten uitvoer te bring. Dit is moeilik om tussen die twee verklarings te kies, maar twee oorwegings steun Jewett se interpretasie. Eerstens versterk sy siening die oorredende krag van Paulus se verduideliking van die geheim, wat net God kan uitvoer; en tweedens verwys dit na die geheim self, wat vir ons as mense so onverstaanbaar is. Dit bly 'n geheim!

Met uittreksels uit Jesaja 27:9 en 59:20-21 bevestig Paulus nou sy verduideliking van die geheim oor Israel se toekomstige verlossing (11:26b-27). Die funksie van sulke argumente gebaseer op die gesag van die Skrif is reeds by herhaling uitgewys: hulle oorreed omdat hulle deur die lesers as gesaghebbend aanvaar word en vir hulle die einde van alle teëspraak beteken.

In 11:28-32 lewer Paulus kommentaar op 11:25-27 en verduidelik hy die betekenis van die geheim van God se verlossingsplan. Die kommentaar kom saaklik op die volgende neer: die Jode het die evangelie verwerp en dit was tot die heidene se voordeel. Vanweë God se verbond met die aartsvaders, bly hulle egter sy uitverkore volk. Paulus se opmerkings in 11:28 bevestig dus sy stelling in 11:26a dat die hele Israel gered sal word. Die geheim behels dat God Israel se verwerping van die evangelie gebruik het om die heidene te laat deel in sy verbond met sy volk.

Vers 29 verseker die lesers dat God sy plan nie sal verander ten opsigte van die genadegawes wat Hy aan mense gegee het en ten opsigte van sy roeping nie. Hierdie versekering verskaf die rede vir Israel se uitverkiesing in 11:28 - soos

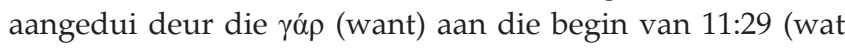
nogeens nie in die 1983-vertaling vertaal is nie, maar wel in die 2014-vertaling). Wat God dus doen, staan vas. In 11:30 word die feit toegepas op die heidene ('julle') en in 11:31 op die Jode ('hulle'), en wel aan die hand van die bekende 'soos-so'skema, gegiet in 'n chiastiese struktuur (Käsemann 1980:316). Die 2014-vertaling van verse 30 en 31 lees: ‘Want net soos júlle voorheen aan God ongehoorsaam was, maar nou ontferming (A) ontvang het weens húlle ongehoorsaamheid (B), so is ook hulle nou ongehoorsaam (B) weens die ontferming (A) wat julle ontvang het, sodat ook hulle nou self ontferming kan ontvang.' Die funksie van hierdie retoriese struktuur is om te beklemtoon dat die situasie van die Jode en die heidene parallel is in hulle ontvangs van ontferming, ondanks die ongehoorsaamheid van elke groep in die verlede. Net soos die heidense christene in Rome voorheen ongehoorsaam was en nou God se ontferming ontvang het, net so sal Israel se huidige ongehoorsaamheid oorkom word deur dieselfde ontferming van God.

Die hele uiteensetting word netjies saamgevat in 11:32: 'God het almal onder die ongehoorsaamheid ingesluit, sodat $\mathrm{Hy}$ aan almal ontferming kan betoon.' Dit beteken dat alles wat Paulus gesê het oor Israel se verharding op 'n tydelike toestand gedui het met die uiteindelike doel om alle nasies 


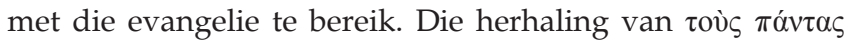
('almal', 'alle mense') in 11:32 is die hoogtepunt van een van die belangrikste temas in die hele brief en kom neer op die 'final reconciliation of the whole world to God through the triumph of mercy' (Dunn 1988:697; vergelyk ook Kim 2000:139). Laasgenoemde beklemtoon die belangrikheid van Paulus se beoogde besoek aan Spanje. As dit afgehandel is, het die hele wêreld die evangelie gehoor en kan die einde kom.

Retoriese tegnieke wat in 11:25-32 gebruik is sluit die volgende in:

- Vers 28 bind asindeties aan die voorafgaande 11:25-27, wat ' $n$ aanduiding is dat Paulus na ' $n$ volgende aspek in sy bespreking van die geheim beweeg.

- Verder bevat 11:28 twee interessante retoriese tegnieke. Eerstens die paromoiosis, waarop Siegert (1985:174)

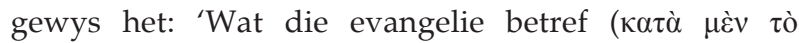

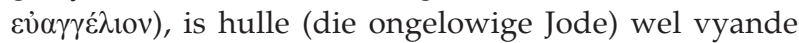
( $\dot{\varepsilon} \chi \rho \rho i ́)$ van God, en dit kom julle (heidene) ten goede

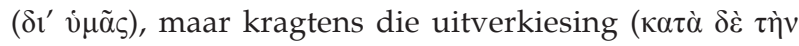
$\dot{\varepsilon} \kappa \lambda \circ \gamma \eta \dot{v}$ ) is hulle geliefdes ( $\dot{\alpha} \gamma \alpha \pi \eta \tau o i ́)$ om die aartsvaders

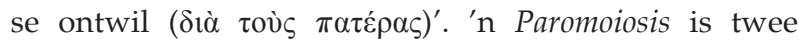
stylvol gebalanseerde frases met dieselfde lengte en sinstruktuur, maar met verskillende betekenisse (Nida et al. 1983:180-181). Hier word dit gebruik om die geheim van God se verlossingsplan te beklemtoon. Tweedens staan die herhaling van dieselfde uitgange by $\dot{\varepsilon} \chi \theta \rho o i ́$ en $\grave{\alpha} \gamma \alpha \pi \eta \tau o i ́$, sowel as die - $\alpha \varsigma$ in $\dot{v} \mu \tilde{\alpha} \varsigma$ en $\pi \alpha \tau \dot{\varepsilon} \rho \alpha \varsigma$, tegnies bekend as homoioptoton, met ' $n$ hoofsaaklik aangename retoriese effek.

\section{Romeine 11:33-36: Alle eer aan God}

Diegedig in 11:33-36is dielangstevanal Paulus se doksologieë en is al breedvoerig in al die standaardkommentare ontleed (vgl. Jewett 2007:713-723 vir'n volledige bespreking). Volgens Louw (1979:117-120) vorm dit die afsluiting en klimaks van die bespreking in hoofstukke 9-11, waarin Paulus die posisie van Israel bespreek het in terme van die sentrale tema van die hele brief, naamlik regverdigmaking deur die geloof alleen. Die onmiddellike aanleiding tot die doksologie is egter die geheim van God se verlossingstrategie in 11:25-32.

Louw (1979:118) verdeel die gedig in drie dele: God se grootheid (11:33); die mens se onvermoë om die grootheid te begryp (11:34-35) en ten slotte: God is groot, die mens is niks - aan Hom dus al die eer (11:36).

Die gedig word gekenmerk deur die herhaling van woorde of gedagtes in drievoud. Die uitroep waarmee dit begin (\%), asook die daaropvolgende frase se $\dot{\omega} \varsigma$, is merkers van emosie. Die lied wat volg, kan tereg beskryf word as ' $n$ argument gebaseer op emosie, met die toon van uitbundige vreugde en verwondering. Die argument berus op die noue band tussen Paulus en sy gehoor, wat meebring dat hulle graag sal wil doen wat hy wil hê hulle moet doen (Tolmie 2005:156). Hulle moet deel in die vreugde van God se unieke verlossingsplan en saamwerk om dit tot voltooiing te bring.
Louw en Nida (1988:687) vertaal 11:33 soos volg: 'How exceedingly great are God's riches, wisdom and knowledge'.

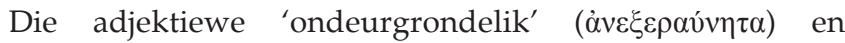

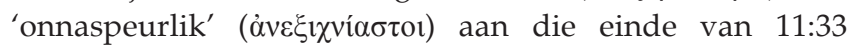
word hier as sinonieme gebruik en die uitroepe word vertaal met: 'How impossible it is to understand his decisions and to comprehend his ways' (Louw \& Nida 1988:383). Binne

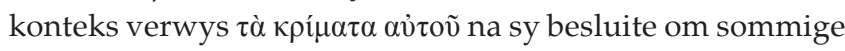
takke van die olyfboom af te breek en ander daarop te ent. Die drie kenmerke van God (rykdom - A, wysheid - B en kennis - C) in 11:33 word in 11:34-35 in omgekeerde orde herhaal: 'Wie het die gedagte (C) van die Here geken, of wie was sy raadsman (B) gewees, of wie het eers iets aan Hom gegee dat dit hom vergeld moet word (A)?' (Schlier 1977:345). Die funksie van die chiastiese struktuur is om deur die besondere ordening van gedagtes die aandag van die gehoor op die inhoud daarvan te vestig. Verder is die drie vrae in 11:34-35 drie Skrifsitate uit Jes. 40:13 en Job 41:3, wat as argumente gebaseer op die gesag van die Skrif die einde van alle teenspraak beteken het en die gehoor moes oorreed van God se grootheid.

Die gedig sluit af met die bekende 'Want uit Hom ( $\dot{\varepsilon} \xi$

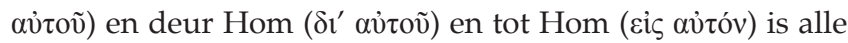

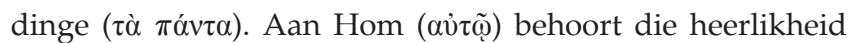
tot in ewigheid. Amen' (11:36). Die drie voorsetselfrases moet ook binne konteks verstaan word. 'Uit Hom en deur Hom' verwys na verlossing deur die geloof, wat in 11:32 as 'ontferming' beskryf is, terwyl 'tot Hom' dui op God as die doel van alles wat in hoofstuk 11 bespreek is: Israel wie se sondes vergewe is (11:27), die Jode en die heidene wat in God se koninkryk van genade opgeneem is $(11: 12,25)$ en alle mense, aan wie genade betoon sal word (11:30-32). Deur die klimaks in die lied word die gehoor oorreed om in te stem tot die voorafgaande argument - insluitend die geheim in 11:25-32 - en hulle samewerking te gee in enigiets wat Paulus dalk van hulle kan vra.

\section{Retoriese tegnieke in die gedig sluit in:}

- Die parachēsis aan die einde van 11:33, wat 'n estetiese funksie het. Die adjektiewe, $\alpha \dot{v} \varepsilon \xi \varepsilon \rho \alpha v ́ v \eta \tau \alpha$ en $\alpha \dot{v} \varepsilon \xi 1 \chi v i ́ \alpha \sigma \tau o l$, begin albei met die sogenaamde alfa-privatief en die twee woorde klink dieselfde. Die sinsdele waarin hulle voorkom, het ook presies dieselfde struktuur, wat tegnies bekend staan as parison (Nida et al. 1983:180).

\section{Gevolgtrekking}

Die bevinding van die studie is dat Tolmie se voorstel vir 'n teksgesentreerde retoriese analise van Paulus se briewe 'n sinvolle alternatief bied vir bestaande benaderings. In die studie is Romeine 11 afgebaken op grond van retoriese oorwegings en in vier dele verdeel: 11:1-10; 11:11-24; 11:25-32 en 11:33-36. In die analise van elke gedeelte is gefokus op die wyse waarop Paulus argumenteer, op die tipes argumente wat hy gebruik en op die retoriese tegnieke wat in die kommunikasieproses gebruik word. Sy argumentasie is veral gekenmerk deur antiteses en die 
metafoor van die olyfboom in 11:16b-24, terwyl voorbeelde van argumente gebaseer op eie ervaring, op die gesag van die Skrif, op goddelike betrokkenheid, op voorbeeld en op emosie ook gevind is. Hy maak ook meer as een keer gebruik van die argument a minore ad maius en verhoog die trefkrag van sy kommunikasie deur middel van verskeie erkende retoriese tegnieke. Sy doel daarmee is om sy gehoor te oorreed tot sy siening van Israel se posisie in terme van regverdigmaking deur die geloof, sowel as tot samewerking in sy beoogde sending na Spanje.

Enkele vertalingsvoorstelle het uit die studie voortgevloei, wat belangrik kan wees om die logiese gang en oorredingskrag van die hoofstuk versterk. Dit betref verse 14, 20, 23-24 en 29 van hoofstuk 11.

\section{Erkenning \\ Mededingende belange}

Die outeur verklaar hiermee dat hy geen finansiële of persoonlike verbintenis het met enige party wat hom nadelig of voordelig kon beïnvloed het in die skryf van hierdie artikel nie.

\section{Literatuurverwysings}

Anderson, R.D., 2000, Glossary of Greek rhetorical terms connected to methods of argumentation, figures and tropes from Anaximenes to Quintilian, Peeters, Leuven. (CBET 24)

Dunn, J.D.G., 1988, Romans 1-8; Romans 9-16, 2 vols., Word, Dallas, TX. (WBC 38a, $38 \mathrm{~b})$
Esler, P.F., 2003, Conflict and identity in Romans, Fortress Press, Minneapolis, MN.

Fitzmyer, J.A., 1993, Romans. A new translation with introduction and commentary, Doubleday, New York, NY.

Harrison, J.R., 2003, Paul's language of grace in its Graeco-Roman context, MohrSiebeck, Tübingen. (WUNT 172).

Jewett, R., 2007, Romans. A commentary, Fortress Press, Minneapolis, MN.

Käsemann, E., 1980, Commentary on Romans, transl. G.W. Bromiley, Eerdmans, Grand Rapids, Ml.

Kim, J.D., 2000, God, Israel and the Gentiles: Rhetoric and situation in Romans 9-11, Scholars Press, Atlanta, GA. (SBLDS 176).

Lenski, R.C.H., 1961, The interpretation of St.Paul's epistle to the Romans, Augsburg Publishing House, Minneapolis, MN.

Louw, J.P., 1979, A semantic discourse analysis of Romans, 2 vols., University of Pretoria Press, Pretoria.

Louw, J.P. \& Nida, E.A., 1988, Greek-English lexicon of the New Testament based on semantic domains, 2 vols., United Bible Societies, New York, NY.

Maartens, P. J., 1997, 'Inference and relevance in Paul's allegory of the wild olive tree', HTS Teologiese Studies/Theological Studies 53(4), 1007-1019. http://dx.doi. org/10.4102/hts.v53i4.1758

Nida, E.A., Louw, J.P., Snyman, A.H. \& Cronje, J.v.W., 1983, Style and discourse, Bible Society of South Africa, Goodwood.

Reid, M. 1995, 'Paul's rhetoric and mutuality: A rhetorical reading of Romans', in SBL Seminar Papers, pp. 117-139, Scholars Press, Atlanta, GA.

Schlier, H., 1977, Der Römerbrief, Herder, Freiburg. (HThKNT 6).

Siegert, F., 1985, Argumentation bei Paulus gezeigt an Röm 9-11, Mohr-Siebeck, Tübingen. (WUNT 34).

Stanley, C.D., 1998, 'Biblical quotations as rhetorical devices in Paul's letter to the Galatians', in SBL Seminar Papers, pp. 700-730, Scholars Press, Atlanta, GA.

Talbert, C., 2002, Romans, Smyth and Helwys, Macon, GA

Tobin, T.H., 2004, Paul's rhetoric in its context: The argument of Romans, Hendrickson, Peabody, MA.

Tolmie, D.F., 2005, Persuading the Galatians. A text-centred rhetorical analysis of a Pauline letter, Mohr-Siebeck, Tübingen. (WUNT 2/9).

Wagner, J.R., 2002, Heralds of the Good News: Israel and Paul "in concert" in the letter to the Romans, Brill, Leiden. (NovTSup 101).

Witherington, B., 2004, Paul's letter to the Romans. A Socio-rhetorical commentary, Eerdmans Publishing Company, Grand Rapids, MI. 